\author{
Mirosława Szott \\ Uniwersytet Zielonogórski \\ mirka.szott@wp.pl
}

\title{
Pieśni Papuszy w perspektywie geo- i etnopoetyki
}

\section{Papusza's Songs in the Perspective of Geo- and Ethnopoetics}

\begin{abstract}
Papusza was a unique personality and her songs are unique as well. However, her gypsy literature is not very well known because of its immanent qualities. It is rather considered of secondary importance and is treated only contextually. Its most important aspect is the legend around Papusza. Thus, in this article, I will focus on the literature (embedded in the context of biography and cultural practices). My aim is to look at Papusza's songs from new research perspectives. As a tool for the analysis I will use strategies of reading developed by geopoetics and ethnopoetics, and, marginally, by feminist research. In the centre of the discussion there will be the notion of the space of the forest. The imaging of this site is, in fact, a common area of analysis for the above-mentioned methodologies.
\end{abstract}

Keywords: Gypsy literature, Papusza, geopoetics, ethnopoetics, forest, feminine writing

Streszczenie: Papusza to osobowość wyjątkowa i wyjątkowe są jej pieśni. Jednak jej cygańska twórczość znana jest w mniejszym stopniu ze względu na walory immanentne. Zamiast tego traktowana jest drugoplanowo i jedynie kontekstowo. Najważniejszy bowiem okazuje się aspekt legendotwórczy. Stąd w swoim artykule skoncentruję się na literaturze (osadzonej w kontekście biografii i praktyk kulturowych). Moim celem będzie spojrzenie na utwory Papuszy z nowych perspektyw badawczych. Jako narzędzia do analizy posłużą strategie lektury wypracowane przede wszystkim przez geopoetykę, etnopoetykę, a na marginesie pojawią się odniesienia do badań feministycznych. W centrum rozważań znajdzie się przestrzeń lasu. Obrazowanie tego miejsca stanowi bowiem obszar wspólny wymienionych metodologii.

Słowa kluczowe: literatura cygańska, Papusza, geopoetyka, etnopoetyka, las, kobiece pisanie

„Te barioł romano wesz Andre łakro boliben” („Niechaj w jej niebie rośnie cygański las") ${ }^{1}$ - napisał Jerzy Ficowski w przedmowie do wierszy Papuszy zebranych w tomiku Lesie, ojcze mój. To wyrażone w języku cygańskim życzenie może być punktem wyjścia do rozważań na temat trzech tęsknot w ży-

${ }^{1}$ J. Ficowski, Papusza i jej pieśń [w:] Papusza, Lesie, ojcze mój, tłum. i wstęp. J. Ficowski, Warszawa 1990, s. 20. 
ciu i twórczości Papuszy. Po pierwsze, tęsknoty za lasem, który stał się dla niej utraconym miejscem (i utraconą kulturą, gdyż jedną z podstawowych jej cech był wędrowny tryb życia). Po drugie, za cygańską wspólnotą, z której została wygnana za odsłanianie tajemnic, i po trzecie - choć już nie wprost za szczęściem rodzinnym, którego prawdopodobnie nigdy nie doświadczyła w cygańskiej, patriarchalnej społeczności. Te trzy wymienione deficyty składają się na skomplikowany życiorys, naznaczony cierpieniem i bezsilnością, którego nie sposób przypisać do regionu i zamknąć w nim, ponieważ domaga się cygańskiej wolności i nieprzywiązania do miejsca.

Zauważyć można w ostatnich latach ogromne zainteresowanie postacią cygańskiej poetki. Powstały dwie ważne książki na temat jej życia: Papusza Angeliki Kuźniak (2013) oraz Bronistawa Wajs Papusza. Między biografią a legendą Magdaleny Machowskiej (2011). Dużą popularnością cieszył się także film Joanny Kos-Krauze i Krzysztofa Krauzego Papusza (2013), który zdobył dwadzieścia dwie nagrody. Nie można zapomnieć też o książce zredagowanej przez Krystynę Kamińską na początku lat dziewięćdziesiątych (Papusza, czyli Wielka tajemnica ${ }^{2}$ ), w której zebrane zostały najważniejsze wypowiedzi na temat Papuszy, wydrukowane wcześniej na łamach czasopism. Odnajdziemy tu głos Jerzego Ficowskiego, Juliana Przybosia, Andrzeja Krzysztofa Waśkiewicza, Tadeusza Kajana, Janusza Koniusza, Henryka Szylkina, Czesława Sobkowiaka, Zygmunta Trziszki, Zdzisława Morawskiego i innych. W podobnym czasie ukazała się również skromna publikacja Leszka Bończuka Papusza, czyli wolność tajemna ${ }^{3}$, w której inicjator Stowarzyszenia Twórców i Przyjaciół Kultury Cygańskiej zamieścił utwory dedykowane Papuszy wraz z krótkim posłowiem na temat fenomenu cygańskiej poetki.

Polskie Gypsy studies zaowocowały pracami przede wszystkim Jerzego Ficowskiego, a także Lecha Mroza (który jako pierwszy w Polsce dogłębnie opisał dzieje Cyganów ${ }^{4}$ ), Adama Bartosza i Andrzeja Mirgi. Ich badania dotyczyły głównie problematyki socjologicznej, antropologicznej, etnologicznej (rzadko była to analiza dyskursu literackiego $\left.{ }^{5}\right)$. W ostatnich latach można zauważyć rozkwit polskiej cyganologii - między innymi warto wspomnieć o konferencjach i seminariach organizowanych przez Piotra Borka (redaktora kilku monografii o tej tematyce ${ }^{6}$. Jedną z najnowszych publikacji jest też książka Anny

2 Papusza, czyli Wielka tajemnica, wyb. tekstów i posł. K. Kamińska, Gorzów Wielkopolski 1992.

${ }^{3}$ L. Bończuk, Papusza, czyli wolność tajemna, Gorzów 1996.

${ }^{4}$ L. Mróz, Dzieje Cyganów-Romów w Rzeczpospolitej XV-XVIII w., Warszawa 2001.

${ }^{5} \mathrm{Na}$ przykład A. Mirga i L. Mróz wymieniają kilku pisarzy cygańskich tworzących po Papuszy (Matteo Maximoff, Menyhért Lakatos, Rajko Djurić), ale ich utworów nie omawiają. Zob. A. Mirga, L. Mróz, Cyganie. Odmienność i nietolerancja, Warszawa 1994, s. 285-286.

${ }^{6}$ Romowie w Polsce i Europie - historia, prawo, kultura, red. P. Borek, Kraków 2007; O Romach $w$ Polsce i Europie. Tożsamość, historia, kultura, edukacja, red. P. Borek, Kraków 2009; Studia o Romach w Polsce i w Europie, red. P. Borek, Kraków 2013. 
Sobieskiej Dzieci Hagar. Literackie wizerunki Romów/Cyganów. Studia imagologiczne ${ }^{7}$, w której badaczka wpisuje wizerunek Cyganów w schematy ujmowane jako trzy mity: przestępczy, erotyczny i muzyczny ${ }^{8}$.

Waśkiewicz zapytany w latach siedemdziesiątych w radiowym wywiadzie przeprowadzonym przez Annę Sobecką o lubuskie środowisko literackie odpowiedział jednoznacznie, że najciekawszym zjawiskiem artystycznym jest na Ziemiach Zachodnich Papusza. Nie była to odosobniona opinia. I mimo upływu wielu lat chyba nic się w tej sprawie nie zmieniło. Biografia romskiej poetki stanowi jeden z najbardziej interesujących poetyckich życiorysów XX wieku. Równie intrygujące są kwestie związane z twórczością Papuszy. Znamienne, że do tej pory nie istnieje żadne omówienie jej utworów dokonane przez badaczy orientalistów (choć zachęcał do takiej próby Waśkiewicz okoto czterdzieści lat temu ${ }^{9}$ ). Do dziś trudno ustalić, mając jedynie dostępne do analizy tłumaczenia Ficowskiego, jak dalece przekład jej utworów odbiega od oryginału. Powtórzę tylko, że wersja niektórych tekstów z Pieśni mówionych (1973) różni się znacząco od tych, które znajdziemy w Pieśniach Papuszy (1956). Ale czy to wskazywałoby - traktując w uproszczeniu sprawy z zakresu translatologii - na przekroczenie kompetencji translatorskich przez Ficowskiego? Nie rozstrzygając tej kontrowersyjnej sprawy, Bończuk przytacza słowa tłumacza:

Nigdy nie zdarzyło mi się (...), żebym cokolwiek Papuszy dopisał. Pewne rzeczy z zapisów rękopiśmiennych pomijałem. Gdybym traktował Papuszę i jej utwory jako osobliwość folklorystyczną, to wówczas jako folklorysta tłumaczyłbym wszystko, co napisała. Dla mnie - była poetką. Tam, gdzie w jej wierszach były słabsze fragmenty, to zwyczajnie omijałem je dla dobra całości ${ }^{10}$.

Nie tylko dla folklorysty miałoby to znaczenie, ale także dla współczesnego literaturoznawcy, którego zakres zainteresowań rozszerzył się o antropologię, etnologię i wiele innych dziedzin humanistyki. We wcześniejszych rozważaniach na temat Papuszy nie były one brane pod uwagę. Być może gdyby teksty Papuszy pojawiły się w druku w całości, ze słabszymi fragmentami (Ficowski wspomina o ich rozwlekłości), byłyby świadectwem jej sposobu myślenia i postrzegania rzeczywistości. Nie tylko wartość artystyczna tych tekstów jest tu bowiem istotna.

${ }^{7}$ A. Sobieska, Dzieci Hagar. Literackie wizerunki Romów/Cyganów. Studia imagologiczne, Warszawa 2015.

8 Tamże, s. 299.

9 A.K. Waśkiewicz, Papusza \& Ficowski, „Ziemia Gorzowska”, luty 1974, s. 31-21.

${ }^{10}$ L. Bończuk, dz. cyt., s. 16. 
Papusza w języku cygańskim znaczy lalka. Takie imię otrzymała od matki Bronisława Zielińska (po mężu Wajs). Poetka zmarła w 1987 roku (data urodzenia nie jest ustalona, w dokumentach pojawia się rok 1908, 1909, 1910), zostawiając zaledwie parę książek (Pieśni Papuszy, 1956; Pieśni mówione, 1973; Lesie, ojcze mój, 1990). Część swoich rękopisów, których nie przekazała Ficowskiemu, zniszczyła z powodu różnych lęków i rozwoju choroby psychicznej. Te, które się zachowały, nazywam pieśniami z tego powodu, że wyrastają z głęboko zakorzenionej cygańskiej tradycji oralnej; poza tym - jak pisze Julian Przyboś - „teksty te stanowią tylko osnowę słowną melodii. Papusza wiersze swoje śpiewa" ${ }^{11}$. W społeczności Romów śpiew pełnił od wieków funkcję mnemotechniczną, w ten sposób przekazywali sobie najważniejsze niepisane tradycje. Poetka postanawia dalej wypełniać swoją misję: utrwala śpiew lasu i ziemi. Takie jest jej poetyckie dążenie:

Ziemio moja i leśna,

jestem córką twoją.

Lasy śpiewają, ziemia śpiewa pięknie.

Śpiewanie rzeka i ja składamy

w jedną cygańską piosenkę ${ }^{12}$.

Także realizm tej twórczości i jej sytuacyjny charakter wskazują na myślenie oralne głęboko zakorzenione w kulturze cygańskiej ${ }^{13}$. Nieporadność językowa Papuszy wynika z samouctwa w tej dziedzinie, a zawężony krąg tematyczny z codziennego doświadczenia. Warto podkreślić, że pieśni Papuszy, choć z ludowości wyrastają, nie są ludowe w sensie folklorystycznym (anonimowe, zbiorowe), ale można je tak określić ze względu na ich samorodność i swoistą przedpiśmienność ${ }^{14}$.

Twórczość Papuszy znana jest w mniejszym stopniu ze względu na jej walory literackie. Najważniejszy bowiem okazuje się aspekt legendotwórczy. $\mathrm{Z}$ pewnością pod tym względem Papusza nie ma sobie równych na ziemi lubuskiej. Wielu badaczy zauważa, że jej romskie pochodzenie i barwne życie sprzyjało tworzeniu plotek, niedomówien ( $\mathrm{i}$ „niedolegend”15), a w rezultacie przyczyniło się do powstania legendy literackiej ${ }^{16}$. Krążyły pogłoski o tym, że

11 J. Przyboś, Papusza i pieśń ludowa [w:] Papusza, czyli Wielka Tajemnica, dz. cyt., s. 75.

12 Papusza, Ziemio moja, jestem córka twoja [w:] tejże, Lesie, ojcze mój, dz. cyt., s. 62.

${ }_{13}$ M. Machowska, Bronistawa Wajs Papusza. Między biografią a legendą, Kraków 2011, s. 225.

14 Por. K. Kamińska, Pieśni Papuszy [w:] Papusza, czyli Wielka Tajemnica, dz. cyt., s. 85.

15 Sformułowanie J. Ficowskiego. Zob. L. Bończuk, dz. cyt., s. 11.

16 Por. tamże oraz M. Sobczak, „Czy bajka byto to, czy prawdą?”. Próba demitologizacji Bronistawy Wajs (Papuszy) [w:] Miejsce i tożsamośc. Literatura lubuska w perspektywie poetyki przestrzeni i antropologii, red. M. Mikołajczak, K. Gieba, M. Sobczak, Zielona Góra 2013, s. 359. 
jej wiersze nie tyle spisywał, co pisał Ficowski. Niektórzy wierzyli też, że nad tekstami Papuszy krąży jej duch (nie wychodziły zdjęcia, dochodziło do wypadków, podczas uroczystości upamiętniających zdarzały się burze i silne deszcze). Marika Sobczak przyznaje, że twórczość Papuszy jest rzadko poddawana rzetelnej analizie ${ }^{17}$. Często traktuje się ją drugoplanowo. Stąd w swoim artykule skoncentruję się na literaturze (osadzonej w kontekście biografii i praktyk kulturowych). Celem będzie spojrzenie na utwory Papuszy z nowych perspektyw badawczych. Jako narzędzia do analizy posłużą strategie lektury wypracowane przede wszystkim przez geopoetykę, etnopoetykę, ale też na marginesie znajdą się odniesienia do badań feministycznych. To właśnie obrazowanie przestrzeni lasu stanowi w wypadku omawianej twórczości miejsce wspólne wymienionych metodologii.

Przestrzeń lasu jest najważniejszym elementem poetyckiego świata Papuszy, z którym straciła więź, osiedlając się po wielu latach koczowniczego życia. Można dostrzec dwa jej aspekty obecne w wierszach poetki. Pierwszy koncentruje się na zabiegach antropomorfizacji, maskulinizacji (las jest tu określany jako ojciec, wychowawca, a także jako oblubieniec), natomiast drugi dotyka sfery sakralnej miejsca (las jako miejsce modlitwy, spotkania z Bogiem, symbiozy człowieka z naturą oraz jako miejsce przeklęte). Tematyzacja przestrzeni zasadza się w tym wypadku na „doświadczeniu kontrastu”" które - według Bernharda Waldenfelsa - ewokuje niepokój, poczucie obcości. Podstawowym kontrastem jest w twórczości Papuszy zestawienie wędrownego i osiadłego sposobu życia. To właśnie na tej granicy dzieje się poezja. Liminalność stanowi jej źródło. Innymi kontrastowymi parami będą również opozycje: kobietamężczyzna (obrazowane jako: Cyganka-las), sacrum-profanum.

Przyjmując tę perspektywę badawczą, posługuję się rozumieniem tekstu wypracowanym przez etnopoetykę, która jest próbą słyszenia i czytania poetyckiej twórczości dalekich innych ${ }^{19}$, a którą Eugenia Prokop-Janiec definiuje jako „środki, konwencje, strategie i praktyki literatury opowiadającej o odmienności, inności, obcości kulturowej" ${ }^{20}$. I choć Papusza nie tworzyła z dala od kultury Zachodu, była niejako poza jej wpływem (co wynika z hermetyczności kultury cygańskiej i wzajemnego nieprzenikania). Autorzy książki $C y$ ganie. Odmienność i nietolerancja przyznają, że między innymi silna grupowa więź i solidarność cygańska oddzielała ich od świata nie-Cyganów i była powodem niechęci, nietolerancji wobec nich ${ }^{21}$.

${ }^{17}$ M. Sobczak, dz. cyt., s. 372.

${ }_{18}$ B. Waldenfels, Podstawowe motywy fenomenologii obcego, tłum. Janusz Sidorek, Warszawa 2009, s. 123.

19 E. Prokop-Janiec, Etnopoetyka [w:] Kulturowa teoria literatury 2. Poetyki, problematyki, interpretacje, red. T. Walas, R. Nycz, Kraków 2012, s. 185.

${ }^{20}$ Tamże, s. 187.

${ }^{21}$ A. Mirga, L. Mróz, dz. cyt., s. 17. 
Trzeba zaznaczyć, że Papusza, pisząc o wyobcowaniu, samotności lub na przykład przedstawiając więź z naturą, nie nawiązuje do tradycji literackiej (chociażby romantycznej, w której te kwestie zostały poetycko wyrażone). Dlatego Ficowski podkreśla, że twórczość ta „nie czerpie wzorów znikąd”22 (poza cygańską pieśnią ludowa).

\section{Cygańska geopoetyka}

Zanim przyjrzymy się obrazowaniu przestrzeni w utworach Papuszy, warto najpierw prześledzić rzeczywisty szlak jej wędrówek. Cygańska poetka po ponad czterdziestu latach koczowniczego trybu życia (jej drogi prowadziły przez Wołyń, Podole, Wileńszczyznę aż do Ziem Zachodnich, od Szczecina po Dolny Śląk $)^{23}$ osiedliła się na zachodnich rubieżach kraju. Najpierw w Wieprzycach, Witnicy, a dopiero później w Żaganiu (1950) i - w wyniku nakazu osiedlenia (akcja osiedleńcza i produktywizacyjna Romów były elementami polityki państwowej PRL) - w Gorzowie Wielkopolskim (1953). Zmarła natomiast w Inowrocławiu. Jej pierwszy tomik pieśni ukazał się dopiero w roku 1956, czyli kilka lat po osiedleniu. Z jednej strony można - za Ficowskim przyjąć, że brak podróżnej scenerii domagał się jakiejś kompensaty i właśnie twórczość dała Papuszy możliwość dopełnienia ${ }^{24}$. Jej pieśni byłyby wtedy niejako produktem ubocznym zmiany trybu życia. $Z$ drugiej strony Waśkiewicz twierdzi, że „twórczość Papuszy mogła istnieć tak długo, jak żywe były wspomnienia koczowniczego trybu życia. Wraz z ich gaśnięciem gasło też źródło inspiracji poetyckiej, kończyła się twórczość" 25 . Zestawienie tych dwóch stanowisk ujawnia, że wektory tej poezji zwrócone są niejako w przeciwnych kierunkach. Według pierwszej koncepcji twórczość ta skierowana jest na wypełnianie braku. Wtedy pełniłaby funkcję terapeutyczną i miałaby kierunek progresywny. Według drugiej - koncentruje się na przeszłości i reminiscencjach (wtedy nie spełnia funkcji terapeutycznej, ale raczej potwierdza poczucie pustki, niedopasowania, samotności). Co ciekawe, nawet psychiatrzy nie radzili Papuszy zapisywać wierszy (czuła wtedy pulsowanie w skroniach): „Lekarze zabraniają Papuszy przyjmowania piosenek, bo od tego głowa boli. Ale Papusza jest bezsilna! Kiedy nocą przyjdzie cała gromada, wesołych jak ptaszki, to znów smutnych jak drzewo w jesieni - jak się przed nimi obronić, gdzie ukryć?" ${ }^{26}$. Halina Ańska, opisując swoją wizytę u Papuszy, wspomina także, że poetka pewnej nocy doznała olśnienia i zrozumiała, że skoro nie może zapisy-

${ }^{22}$ J. Ficowski, Papusza i jej pieśń [w:] Papusza, Pieśni mówione, wyb., tłum. i wstęp J. Ficowski, Łódź 1973, s. 7.

23 Tamże, s. 10.

${ }^{24}$ Tamże.

25 A.K. Waśkiewicz, Papusza. Szkic do portretów, „Nadodrze” 1963, nr 6, s. 7, 12.

${ }^{26}$ H. Ańska, Papusza, „Nadodrze” 1975, nr 13, s. 8. 
wać pieśni, zacznie je rysować. Czy gdzieś zachowały się te szkice? Z pewnością mogłyby stanowić ciekawy materiał do badań porównawczych.

Warto podkreślić, że wiersze cygańskiej poetki są świadectwem niespotykanego już dziś związku człowieka z przyrodą. Związku, o którym można powiedzieć, że jest pierwotny, symbiotyczny i stanowi niedościgniony ideał dla współczesnych dążeń geopoetyckich. Wisława Szymborska, pisząc o Pieśniach Papuszy w 1952 roku, zwróciła uwagę na wyjątkowe doświadczenie przestrzeni w jej wierszach:

Egzotyka? Tak, jest egzotyka, ale odnajdziemy ją tam, gdzie poetka mówi o lesie, słońcu, ptakach. Takiej zażyłości z lasem, jaką wyrażają jej pieśni, nie spotykamy w polskiej poezji ludowej. W zażyłości tej odbija się najbardziej bezpośrednio i dramatycznie obraz życia wędrownego cygańskiego obozu ${ }^{27}$.

Stąd można mówić o geopoetyce sensu stricto, gdzie las, ziemia i łąki są nie tyle miejscem lub geograficznym określeniem, co żywicielami, utraconym domem oraz ojcem i matką. Geopoetyka ta ma znamiona filozoficznego myślenia o otoczeniu, nie ma natomiast wymiaru ekologicznego w rozumieniu współczesnym. Jest pierwotną praktyką życia codziennego, którą cechuje myślenie symboliczno-magiczne. Mamy tu do czynienia ze szczególną geopoetyką utraconą i jej podwójnym paradoksem:

utracie podlega bowiem to, co samo w sobie jest ulotne i nietrwałe (zjawiska przyrody, towarzyszące wędrownemu życiu), a osiedlenie się w stałym miejscu, zapuszczenie w nim korzeni łączy się z pozbawieniem tożsamości - tak w sensie kulturowym, jak i egzystencjalnym ${ }^{28}$.

Papusza i jej cygański los idealnie wpisują się w kategorie nomady i nomadyzmu, którymi się posłużył Kenneth White. Szkocki poeta ujął swój koczowniczy temperament w kilku słowach: „Ja wolę być w drodze" ${ }^{29}$. W swojej geopoetyckiej filozofii wyszedł od pojęcia „nomady intelektualnego”. Jego zdaniem jest to:

ktoś, kto czuje się ograniczony granicami oraz identyfikacjami, jakie mu się proponuje. (...) On wie, że wszystkie kultury są fragmentaryczne i dlatego wędruje od jednej do drugiej. Może to prowadzić do eklektyzmu. Ale wówczas przychodzi czas na refleksję, której celem jest zachowanie istoty rzeczy ${ }^{30}$.

${ }^{27}$ W. Szymborska, Pieśni Papuszy, „Życie Literackie” 1956, nr 19, s. 16.

${ }^{28}$ M. Mikołajczak, Co zostato na dnie „kulturowego tygla”? Powroty do miejsc utraconych w twórczości najstarszego pokolenia lubuskich poetów [w:] tejże, Zbliżenia. Studia i szkice poświęcone literaturze lubuskiej, Zielona Góra 2011, s. 67.

${ }^{29}$ K. White, Geopoetyki, wyb., tłum. K. Brakoniecki, Olsztyn 2014, s. 31.

30 Tenże, Poeta kosmograf, wyb., tłum. K. Brakoniecki, Olsztyn 2010, s. 7. 
Nomada przez poznanie licznych kultur nie staje się jednak ani relatywistą, ani pluralistą, tworzy nową koherencję, która mieni się wszystkimi lokalnymi kolorami ${ }^{31}$. Podobnie jest z Cyganami, którzy nie prowadzili osiadłego trybu życia. Jednak posiadali na tyle hermetyczną i konserwatywną kulturę, że ich nomadyzm ulegał wpływom o wiele wolniej niż ten, o którym pisze White. W pieśniach cygańskich pobrzmiewały jeszcze indyjskie historie przodków, a ustny przekaz w czasach życia Papuszy był jedyną niepisaną tradycją, która zmieniała się pod wpływem nowych szlaków oraz poznawanych kultur. Papusza musiała złamać tradycję. Jej poezja okazuje się nieświadomym znakiem odwagi, prowadziła ją do emancypacji (kulturowej, płciowej), naruszenia cygańskiego kodeksu zakazów tabuicznych - mageripén (który stoi na straży tajemnic języka cygańskiego), a których skutkami były odrzucenie, samotność, a także choroba psychiczna.

Kultura cygańska to tradycyjna kultura patriarchalną, w której najważniejsze miejsce zajmuje mężczyzna („Mąż zawsze ma rację. On jest górą, on twoim panem"32). Po ślubie kobieta wchodzi do rodziny męża (w myśl patrylokalności), zostaje podporządkowana całkowicie teściowej, spełnia jej polecenia, może być przez nią karana ${ }^{33}$. Kobieta niewiele różni się od rzeczy, ma spełniać funkcje praktyczne: jej obowiązkiem jest zarabianie pieniędzy, służenie mężowi i rodzenie dzieci. Papusza świetnie radziła sobie z pierwszym wspomnianym zadaniem. Wróżyła, potrafiła też przynieść do domu kurę. Dzieci własnych nie miała. A warto wspomnieć, że w tej kulturze kobieta stawała się w pełni żoną dopiero, gdy urodziła dziecko ${ }^{34}$. Przysposobiła syna, którego nazywała Tarzan. Jakże symptomatyczna staje się w tym kontekście figura lalki (przedmiotu do zabawy, pięknej i niemej marionetki), którą została naznaczona w dzieciństwie. Warto przez pryzmat kontekstu kulturowego przyjrzeć się opisywanej przez nią przestrzeni, zwłaszcza z punktu widzenia kobiecego pisania. Tym bardziej że las - jeden z najważniejszych elementów jej zapisanego świata - jest tu najczęściej obrazowany jako mężczyzna (ojciec, Bóg, oblubieniec). Pojawia się niemal w każdym utworze i gdyby stworzyć słownik frekwencyjny poezji tej cygańskiej pisarki, zająłby z pewnością pierwsze miejsce. Las w tych cygańskich wierszach jest to „nie tylko element krajobrazu, ale wyraziciel uczuć, powiernik wzruszeń, liryczny współbohater utworów" ${ }^{35}$. I właśnie temu antropomorfizowanemu miejscu nie-miejscu i jego ludowemu obrazowi zamierzam się szczegółowo przyjrzeć.

31 Tenże, Geopoetyki, dz. cyt., s. 24.

32 A. Kuźniak, Papusza, Wołowiec 2013, s. 36.

${ }_{33}$ A. Mirga, L. Mróz, dz. cyt., s. 260.

${ }^{34}$ Tamże, s. 260.

35 J. Ficowski, Papusza i jej pieśń [w:] Papusza, czyli Wielka Tajemnica, dz. cyt., s. 121. 


\section{Las jako mężczyzna}

Słowo „las” niesie bardzo bogaty ładunek symboliczny. Może oznaczać Ziemię, duszę, ukrycie, schronienie, świątynię, pustelnię, miejsce czarów i jednocześnie marzenie senne, miejsce miłosnych spotkań, płodność oraz podświadomość (ciemny las - wł. selva oscura) ${ }^{36}$. Las Papuszy pozbawiony jest wielu z tych skojarzeń, ponieważ stanowi podstawową przestrzeń życia. Jednak można przypuszczać, że cygańska poetka intuicyjnie czuje, że miejsce to stanowi domenę pragnień, pożądań i ukrytych tęsknot.

Najczęstszym określeniem lasu w pieśniach Papuszy jest przymiotnik „czarny”. Poetka równie często opisuje w ten sposób ludzi społeczności cygańskiej (przy czym w jej utworach zdecydowanie częściej pojawiają się kobiety niż mężczyźni). Co ciekawe, syndrom „czarności”, który uzupełniał syndrom złodziejskości - jak pisze Sobieska - prześladował nawet badaczy, naukowców, popularyzatorów wiedzy o Cyganach ${ }^{37}$. Na przykład Ignacy Daniłowicz opisywał karnację Cyganów jako konsekwencję brudu oraz przebywania w pobliżu ognia i dymu: „Płeć brunatno żółta, nie tyle z natury, we wszystkich klimatach jest niezmienna, jak raczej z obrzydliwej nieczystości, i skwarzenia przy ogniu lub dymie w stłuszczone brudy zawiniętego niemowlęcia"38.

Według Stownika symboli Władysława Kopalińskiego kolor czarny wiąże się zazwyczaj ze zjawiskami i cechami negatywnymi - z ciemnością, złem, niemoralnością, śmiercią̧ ${ }^{39}$. Jednak w wierszach Cyganki nie ewokuje on takich skojarzeń. Czarna jest noc, ale też jaskółka, jagody, ziemia. Poetka znajduje w ten sposób wspólne cechy najbliższego otoczenia i stereotypowego obrazu Cygana (który ma serce osmalone słońcem ${ }^{40}$ ). Według niej to jedna płaszczyzna, wspólny mianownik do rozpatrywania losu człowieka i przyrody. Dlatego gdy Cygan zostaje przesiedlony (umiejscowiony) z lasu do domu, to jego serce kamienieje („Ich stare serca jak kamienie:/ w lesie wyrosły/ i skamieniały”¹1), a w innej wersji tego wiersza: po prostu zastyga („Starych serca się nie zmienią/ a podobne są kamieniom" ${ }^{2}$ ).

Papusza nadaje cechy ludzkie przestrzeni, za którą tęskni. Kuźniak przywołuje fragmenty jej pamiętnika, kiedy pisze ona o niespełnionej miłości, tęsknocie za Witoldem. Papusza była wówczas już żoną Dionizego, nie potrafiła go opuścić: „Matka zawsze mi zabraniała żebym Dyśka nie zostawiła, bo ona biedna tesz była nieszczęśliwa z Wajsem pijakiem, ale pokornie cier-

36 W. Kopaliński, Stownik symboli, Warszawa 2006, s. 186-188.

${ }^{37}$ A. Sobieska, dz. cyt., s. 56.

38 I. Daniłowicz, O Cyganach wiadomość historyczna [Wilno 1824], wstęp L. Mróz, Oświęcim 1993, s. 15. Cyt. za: A. Sobieska, dz. cyt., s. 56.

39 W. Kopaliński, dz. cyt., s. 48-49.

40 Papusza, Pieśń cygańska z Papuszy gtowy utożona [w:] tejże, Pieśni mówione, dz. cyt., s. 47.

${ }^{41}$ Taż, Na dobrej drodze [w:] tejże, Pieśni mówione, dz. cyt., s. 43.

42 Tamże. 
piała i mi też kazała cierpieć i ja ją słóchałam”³. Być może ta jej tęsknota za lasem jest połączona z pragnieniem prawdziwej miłości, której nigdy nie doświadczyła jako żona Wajsa. Papusza była nadwrażliwą osobą, zdarzało jej się doświadczać psychosomatycznych dolegliwości. Na przykład po pożegnaniu z Witoldem pisze o tym, jak zachorowała: „Więcej z żaló nisz z choroby. Sama nie wiem co to za choroba czy ómysłowa czy nerwowa. A może sercowa. Jakieś dóchy mię opanowali”" ${ }^{4}$. W jej tekstach poetyckich nie odnajdzie się tematu miłości; erotyzm zarezerwowany jest dla zjawisk przyrody. Niemniej Zdzisław Morawski zauważa, że wszelkie jej omamy, wypowiedzi o prześladowaniu miały w tle erotykę („to mąż wypędzał ją z łóżka, bo chciał przyjąć synową, to mąż chciał ją zaspokajać przez dostawianie do niej zwierząt, to sąsiadka chciała współżyć z synem” ${ }^{45}$ ). Można przypuszczać, że wszystkie swoje uczucia i pragnienia przekierowała na pisanie o lesie.

Las w tekstach Papuszy jest zdolny do miłości i bywa dla niej źródłem natchnienia. Poetka za pomoca gry kolorami pokazuje wymiar omnitemporalny lasu i jednocześnie pieśni, które - według jej wyobrażeń - po jej śmierci tam zostaną:
Pokochał mnie las,
dał mi cygańskie słowo
(...)
dziś, jutro życie mi się skończy
i w lesie moim zostaną
moje niemądre pieśni
I zaśpiewa je las
czarny, zielony, czerwony ${ }^{46}$.

Można by postawić tezę, że las to jedyna prawdziwa i niespełniona miłość pisarki. Być może dlatego przeniosła ona męskie cechy na krajobraz, poddając go jednocześnie idealizacji. Z nim też związana jest romantyczna aura, w opisach można znaleźć księżyc, noc, ognisko.

A w moim lesie nocami

tuż przy księżycu

ogniska płoną

i światłem biją jak kamienie drogie,

którymi ludzie palce zdobią.

${ }^{43}$ A. Kuźniak, dz. cyt., s. 44 [zachowano pisownię oryginalną].

44 Tamże.

${ }^{45}$ Z. Morawski, Wszystko co wiem o Papuszy [w:] Papusza, czyli Wielka tajemnica, dz. cyt., s. 54.

46 Papusza, Las [w:] tejże, Pieśni mówione, dz. cyt., s. 22. 
Ach, moje lasy ukochane,

pachnące zdrowiem!

Wychowałyście wy Cyganięta

jak swoje własne zagajniki

Wiatr sercem jak liść porusza

i bać się nie ma czego.

Dzieciaki śpiewają sobie,

czy spragnione, czy głodne

skaczą i tańczą,

bo las je tak nauczył ${ }^{47}$.

Także w tytule wiersza Lesie, ojcze mój podkreślona została bliska relacja podmiotu i miejsca. Porównanie lasu do ojca jest tu uzasadnione osobistymi przeżyciami poetki (straciła ojca jako dziecko). Las-mężczyzna to wychowawca, autorytet, ale jednocześnie ten, który odrzuca:

Lesie, ojcze mój,

czarny ojcze,

ty mnie wychowałeś,

ty mnie porzuciłes ${ }^{48}$.

Utwór ten zbudowany został z wielu paralelizmów. Najpierw aktywną stroną jest las, później dopiero dziewczyna („ty śpiewasz i ja śpiewam/ śmiejesz się i ja się śmieję" $\left.{ }^{49}\right)$. Ich relacja to lustro, dopełnianie. Jednak dominującą stroną okazuje się tu las, ponieważ to on nadaje kierunek działania. Czytelnik zostaje przyzwyczajony do rytmu wiersza, jego wynikowości: „Ty nie zapomniałeś/ i ja cię pamiętam" ${ }^{50}$. Cyganka nie potrafi zapomnieć o lesie, tak samo jak nie umie usunąć ze swojej pamięci wspomnień o ojcu. Mężem Bronisławy Zielińskiej został Dionizy Wajs, brat jej ojca starszy od niej o 23 lata. Młoda Papusza nie mogła się pogodzić z zamążpójściem. Może się wydawać, że Papusza wychowana jako posłuszna Cyganka, nie umiała odmienić swojego losu, nie potrafiła także nic zrobić, kiedy Cyganie zostali zmuszeni do osiedlenia się. Nie do końca tak jest. Nauka czytania i pisania, a później również tworzenie literatury stały się dla niej sposobem na wyrażenie niezgody. Jej teksty uwidaczniają tęsknotę i nierozumianą przez nią samą bezradność.

W wierszu Lesie, ojcze mój pojawia się motyw lasu-wychowawcy. To on nauczył cygańskie dzieci pełnej radości, zaufania wobec natury. Stały się one

\footnotetext{
${ }^{47}$ Taż, Leśna pieśń [w:] tejże, Pieśni mówione, dz. cyt., s. 38.

48 Taż, Lesie, ojcze mój [w:] tejże, Pieśni mówione, dz. cyt., s. 19.

49 Tamże.

50 Tamże.
} 
jego integralną częścią, wrosły w jego ekosystem. Literacki świat Cyganki musi więc obfitować w leśne metafory (tym bardziej że wędrowny tryb życia został utracony). Stąd też porównania dziewczyn do czarnych jagód (Kolczyk z liścia), dzieci do borowików (Na śladach ognisk grzyby wyrosty). W wierszu W maju Papusza tworzy tradycyjny obraz tęsknoty:

Siedzę w domu i przez okno widzę,

jak ptak przefruwa i bije skrzydłami

Zielony las przyciaga oczy

i pachnie, że aż płaczą serca ${ }^{51}$.

Ona - unieruchomiona (siedzi), a wysłannik lasu cieszy się wolnością (lata). Ale poetka widzi i czuje las, doświadcza go wszystkimi zmysłami, interioryzuje. Relacja jest tu dwustronna, gdyż „za Cyganami biała brzoza płacze" ${ }^{\prime 2}$. Papusza nadaje tekstowi cechę dialogiczności, gdzie podmiot odpowiada poprzez naturę:

Nie płacz dziecino, chodź do lasu, posiedzisz, zapomnisz

Nie płacz dziewczyno, chodź nad wodę,

Usiądź na brzegu ${ }^{53}$.

Nie jest to tylko gra wyobraźni. Cyganka bowiem potrafi czytać naturę, rozumie swoje otoczenie. Pisząc o wędrującej wodzie, zaznacza, iż „domyślić się można,/ że przemówić pragnie” ${ }^{4}$. Nie słowami („bo nie zna żadnej mowy” ${ }^{5}$ ), które przynależą do świata ludzi, ale swoim biegiem, wędrówką („srebrnym pluskaniem i szumem"56). Papusza, pisząc, próbuje przekroczyć perspektywę antropocentryczną. Rozumie, że język ludzi nie jest jedyną możliwością komunikacji. Mircea Eliade wśród cech człowieka epoki rajskiej wymienia przyjaźń ze zwierzętami i znajomość ich języka (poza tym: nieśmiertelność, spontaniczność, wolność, możliwość wniebowstępowania i kontaktowania się $\mathrm{z}$ bogami $)^{57}$. W myśleniu Papuszy można odnaleźć takie cechy, jak: bliski kontakt z ptakami (które nazywa braćmi) oraz łatwość rozmowy z Bogiem. Zatem geopoetyka (nie tylko jej) wyrasta w pewnym sensie z epoki rajskiej.

${ }^{51}$ Papusza, W maju [w:] tejże, Pieśni mówione, dz. cyt., s. 26.

52 Tamże.

53 Tamże.

${ }^{54}$ Papusza, Woda, która wędruje [w:] tejże, Lesie, ojcze mój, dz. cyt., s. 23.

55 Tamże.

56 Tamże.

${ }^{57}$ M. Eliade, Mity, sny i misteria, tłum. K. Kocjan, Warszawa 1994, s. 64. 


\section{Las sakralizowany i przeklęty}

Dla Papuszy przyroda należy do sfery sacrum. Bierze się to zapewne ze sposobu pojmowania ziemi przez Cyganów i czci, którą ją (jako matkę-opiekunkę) otaczają. Machowska zauważa, że najgłębiej zakorzeniona jest w jej tekstach wizja Boga chrześcijańskiego, którego autorka Pieśni mówionych pojmuje panteistycznie ${ }^{58}$. Przejawia się on w każdym elemencie natury, jest wszechobecny. Dlatego dla Cyganki doświadczeniem religijnym okazują się na przykład zachód słońca lub wejście do lasu. W wierszu Tam, gdzie wiatr Papusza przedstawia las jako sanktuarium:

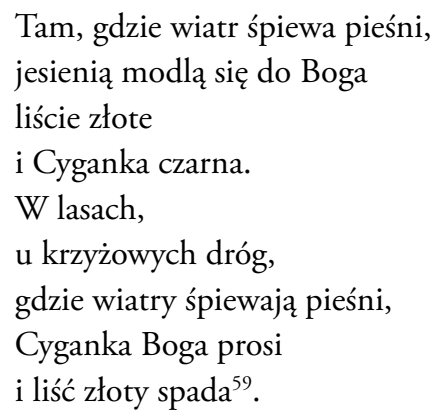

Modlą się nie tylko cygańska kobieta na rozstaju dróg, ale także drobne liście, które niebawem opadną z drzewa. Ciekawe jest tu operowanie kolorem. Jak zwykle u Papuszy Cygankę określa kolor czarny, liście natomiast - kolor złoty. Ma to również wymiar symboliczny. Złoto (kolor złoty) związane jest z boskością, nieśmiertelnością, mądrością i szlachetnością ${ }^{60}$. W większości dialektów języka romani na oznaczenie istoty boskiej stosuje się termin Del (lub Dewel, Dewet, Dewtoro), co wiąże się z sanskryckim diw - świecić, błyszczeć, więc pojęcie boga łączy się z ideą światła, transcendencji ${ }^{61}$.

Gdy Cyganka prosi Boga w modlitwie, to właśnie ten doskonały liść spada dla niej - jak czytamy w ostatnim wersie wspomnianego wiersza. Także w innym utworze cygańska dziewczyna posiada kolczyki z liści: „Już kolczyki z liści dwa/ niby szczerozłote ma" ${ }^{\prime 2}$. Nieco wcześniej w tym samym wierszu odnajdziemy fragment, który mówi o tym, skąd w myśleniu Papuszy powiązanie złotego koloru z liściem: „Złoto w ziemi się schowało,/ drzewo z niego liść wydało" ${ }^{63}$. Złoto to metonimia skarbu, najwyższej wartości, która tkwi w zie-

\footnotetext{
58 M. Machowska, dz. cyt., s. 235.

59 Papusza, Tam, gdzie wiatr [w:] tejże, Lesie, ojcze mój, dz. cyt., s. 25.

${ }^{60}$ W. Kopaliński, dz. cyt., s. 502-504.

${ }^{61}$ A. Mirga, L. Mróz, dz. cyt., s. 218-219.

${ }^{62}$ Papusza, Kolczyk z liścia [w:] tejże, Lesie, ojcze mój, dz. cyt., s. 56.

${ }_{63}$ Tamże, s. 55.
} 
mi. Dlatego zwykły liść (którego ruch skierowany jest ku ziemi) bywa tu obrazowany jako przewodnik, drogowskaz:

Na wszystko pada złoty liść

niesiony przez wiatry -

taki drogowskaz, co prowadzi

we wszystkie strony ${ }^{64}$.

Biżuteria leśna, ozdoby, spódnica z kwiatów są dla Papuszy niejako ekwiwalentami symboli religijnych, znakami jej przynależności. To ciekawe, gdyż spódnica stanowi w cygańskiej kulturze tabu (podźitko mageripen) - uznawana jest za nieczystą część ubrania, ma moc kalającą (więc kobieta może użyć jej w celu samoobrony) ${ }^{65}$. Dla poetki stanowi ona bardzo ważną rzecz - wyraża to wiersz Gdzie jest moja spódnica ze wszystkich kwiatów świata ${ }^{66}$, w którym Papusza opłakuje zagubioną spódnicę („Ludzie jak ja ją szyłam!/ Jak ją układałam" ${ }^{67}$ ), a może próbuje dać do zrozumienia, że opłakuje swoją bezsilność.

Zdaniem Machowskiej Papusza nie uprawia gatunków, które przynależą do liryki religijnej (takich jak psalm, modlitwa) ${ }^{68}$. Rzeczywiście, nie ma w tej twórczości wierszy typowo religijnych. Bo i obraz świata nie jest typowy (dla poezji XX wieku), ufundowany na gotowych przesłankach. Tym właśnie różni się metafizyczny model świata od religijnego, że ten drugi odwołuje się do kanonicznej i gotowej narracji, podczas gdy pierwszy - to hipoteza umysłu, dzieło wyobraźni ${ }^{69}$. Wiersze Papuszy można by rozpatrywać w kategoriach folkloru, gdzie sacrum obecne jest w gatunkach typowo świeckich - pieśniach lub przysłowiach. Jerzy Bartmiński dowodzi:

Dla religii kategoria sacrum jest obligatoryjna. Odniesienie religii do sfery sacrum (...) opiera się na szacunku i czci, przyjmującej formę zbiorowego kultu. W przypadku folkloru - który oparty jest w swoich tradycyjnych formach na myśleniu religijnym i magicznym, na wierze $\mathrm{w}$ istnienie świata duchowego pomocnego lub szkodliwego wobec człowieka - takiej jednoznaczności brak ${ }^{70}$.

${ }^{64}$ Papusza, Na śladach ognisk grzyby wyrosty [w:] tejże, Lesie, ojcze mój, dz. cyt., s. 23.

${ }^{65}$ J. Ficowski, Cyganie w Polsce. Dzieje i obyczaje, Warszawa 1989, s. 61-62.

${ }^{66}$ Papusza, Gdzie jest moja spódnica ze wszystkich kwiatów świata [w:] tejże, Pieśni mówione, dz. cyt., s. 30-31.

67 Tamże.

${ }_{68}^{6}$ M. Machowska, dz. cyt., s. 235.

${ }^{69}$ E. Balcerzan, Religijne i metafizyczne horyzonty polskiej liryki, „Teksty Drugie” 2015, nr 3, s. 290.

${ }^{70}$ J. Bartmiński, Formy obecności sacrum $w$ folklorze [w:] Folklor - sacrum - religia, red. J. Bartmiński, M. Jasińska-Wojtkowska, Lublin 1995, s. 10-11. 
Bóg Papuszy objawia się poprzez naturę, zamieszkuje las. Papusza prosi go o opiekę nad Cyganami - ale jednocześnie też o to, aby zaszkodził Niemcom („prowadź ich drogą zdradziecką/ by żyć mogło cygańskie i żydowskie dziecko" $\left.{ }^{71}\right)$. Jak wynika z jej opisu, Stwórca przychylny jest każdemu stworzeniu, które cierpi:

Dziś ptak w zaroślach śpi pod śniegiem, jak biedne Cyganiątko, co dziś znalazło ciepły dom.

Przyfruwa pod okno biedny ptak, zmarznięty - chleba prosi.

Ach, to mój leśny braciszek!

Razem wyrośliśmy w czarnym lesie.

(...)

Chodź tutaj do mnie, ja do ciebie przyjdę,

ptaku biednusieńki!

Poprosimy Boga oboje,

żeby wielkie słońce nadeszło ${ }^{72}$.

Mircea Eliade stwierdza, że dla człowieka religijnego przestrzeń dzieli się na obszar święty (mocny) i nieuświęcony, amorficzny ${ }^{73}$. Czy takiego podziału dokonuje w swoich wierszach Papusza? W poezji cygańskiej poetki nie sposób odnaleźć chrześcijańskich symboli religijnych (na przykład krzyża) lub miejsc kojarzonych ze sferą sacrum (kościoła, kaplicy). Jej wyobrażenie sakralnej przestrzeni nawiązuje do wyobrażenia Ziemi-Matki i porastającego ją lasu. Zachodnia cywilizacja, która kojarzy się Cygance z czasem osiedlenia (choć trzeba pamiętać, że w zbiorach jej wierszy można też znaleźć teksty agitujące do osiedlania - był to zarzut wobec Ficowskiego, że manipulował poetka), przerwała cygański mityczny czas, który charakteryzował się symbiozą z naturą. Wśród pieśni Papuszy jest też wiersz, w którym poetka pisze o przeklętym lesie:

Nie pójdę już do czarnych lasów, wierzcie mi - niechaj zginę! gdzie wędrowali kiedyś Cyganie.

Bo ta droga - przeklęta!

${ }^{71}$ Papusza, Krwawe tzy co za Niemców przeszliśmy na Wotyniu w 1943 i 44 roku [w:] tejże, Lesie, ojcze mój, dz. cyt., s. 70.

${ }^{72}$ Taż, Zima biata nastata [w:] tejże, Lesie, ojcze mój, dz. cyt., s. 44.

${ }^{73}$ M. Eliade, Sacrum, mit, historia, tłum. A. Tatarkiewicz, Warszawa 1970, s. 61-62. 
(..)

Nie wrócę już na te drogi.

Ja, która kocham las i pieśni leśne,

I wszystko, co żyje i rośnie ${ }^{74}$.

Papusza jest rozdwojona przez swoje sprzeczne pragnienia, ma żywą pamięć o czasach, kiedy doświadczała wolności, i jednocześnie czuje litość wobec cygańskiego, wędrownego losu, który naznaczony był niedogodnościami, cierpieniem i biedą.

Współczesne literaturoznawstwo dostarcza wielu nowych perspektyw, za pomocą których można spojrzeć na twórczość Papuszy. Geopoetyka pozwala pokazać nadzwyczajny związek poetki z naturą w wymiarze panteistycznym, etnopoetyka otwiera furtkę do przyjrzenia się jej tekstom w kategoriach inności/obcości, a badania feministyczne pozwalają oświetlić tę twórczość pod kątem kobiecego pisania o przestrzeni. Teksty Papuszy pozbawione są dystansu między życiem codziennym a twórczością, ilustrują koncepcję arachnologii Nancy K. Miller, gdzie metafora pisarki-pajęczycy i utkanej sieci obrazuje ścisły związek kobiety z jej tekstami ${ }^{75}$.

Papusza to osobowość wyjątkowa i wyjątkowa jest jej cygańska twórczość, której zrozumienia - mimo przekładów Ficowskiego - broni cygański język. Można więc próbować ją odczytywać na różne sposoby, ale prawdopodobnie żaden z nich nie doprowadzi do jednoznacznego rozwiązania tajemnicy. W Niewidzialnych miastach Itala Calvina znajdziemy taki fragment:

Przybywając do każdego nowego miasta, podróżny odnajduje własną przeszłość, o której posiadaniu już nie pamiętał: obcość tego, czym już nie jesteś lub czego nie posiadasz, oczekuje cię przy przejściu przez miejsca obce i nigdy niewzięte w posiadanie. (...) To, co istnieje gdzie indziej, jest odwróconym zwierciadłem ${ }^{76}$.

Nomada podróżuje w poszukiwaniu siebie, swojej przeszłości. Jeśli zabraknie mu „niewziętych w posiadanie” miejsc, nie będzie mógł scalić swojego bytu. Stanie się nieczytelny dla samego siebie i niebezpiecznie rozpro-

74 Papusza, Już moja noga nie postanie, gdzie niegdyś jeździli Cyganie [w:] tejże, Lesie, ojcze mój, dz. cyt., s. 58.

${ }^{75}$ N.K. Miller, Arachnologie: kobieta, tekst i krytyka, tłum. K. Kłosińska, K. Kłosiński [w:] Teorie literatury XX wieku. Antologia, red. A. Burzyńska, M.P. Markowski, Kraków 2006, s. $487-513$.

76 I. Calvino, Niewidzialne miasta, tłum. A. Kreisberg, Warszawa 2013, s. 25. 
szony. Podobnie rzecz ma się z Papuszą i jej niezaspokojonym pragnieniem przemieszczania się wewnątrz natury. To wielkie pragnienie, kompensowane przez samą naturę, a wypowiedziane przez Papuszę w imieniu całej społeczności cygańskiej, można by przedstawić za pomocą fragmentu z wiersza Ficowskiego: „Nieruchomieją. Ziemia jest za nich ruchoma”" Osiedlenie stało się źródłem poczucia obcości i to podwójnej (w węższym sensie - wewnątrz społeczności cygańskiej i obcości w sensie szerszym - w społeczności polskiej). Jej pieśni, które Małgorzata Mikołajczak nazwała „hymnem na cześć dawnego cygańskiego życia oraz związanych z nim miejsc-krajobrazów"78, są symptomem nie tylko samorodnego literackiego talentu i zaangażowania tłumacza. Stanowią niejako lustro Papuszy. Okazują się namacalnym dowodem unieruchomienia cygańskiej melodii i rytmu w zastygniętym słowie i tym samym metaforą ograniczenia przestrzennego.

\section{Bibliografia}

\section{Literatura podmiotu}

Papusza, Lesie, ojcze mój, Warszawa 1990.

Papusza, Pieśni mówione, wyb., tłum. i wstęp J. Ficowski, Łódź 1973.

Pieśni Papuszy, wyb., tłum. J. Ficowski, Wrocław 1956.

\section{Literatura przedmiotu}

Ańska H., Papusza, „Nadodrze” 1975, nr 13.

Balcerzan E., Religijne i metafizyczne horyzonty polskiej liryki, „Teksty Drugie” 2015, nr 3.

Bartmiński J., Formy obecności sacrum w folklorze [w:] Folklor-sacrum - religia, red. J. Bartmiński, M. Jasińska-Wojtkowska, Lublin 1995.

Bończuk L., Papusza, czyli wolność tajemna, Gorzów Wielkopolski 1996.

Calvino I., Niewidzialne miasta, tłum. A. Kreisberg, Warszawa 2013.

Eliade M., Mity, sny i misteria, tłum. K. Kocjan, Warszawa 1994.

Eliade M., Sacrum, mit, historia, tłum. A. Tatarkiewicz, Warszawa 1970.

Ficowski J., Cyganie w Polsce. Dzieje i obyczaje, Warszawa 1989.

Ficowski J., Papusza i jej pieśńn [w:] Papusza, Lesie, ojcze mój, ttum. i wstęp J. Ficowski, Warszawa 1990.

Ficowski J., Papusza i jej pieśń [w:] Papusza, Pieśni mówione, wyb., tłum. i wstęp J. Ficowski, Łódź 1973.

Ficowski J., Pismo obrazkowe, Warszawa 1962.

Kopaliński W., Stownik symboli, Warszawa 2006.

Kuźniak A., Papusza, Wołowiec 2013.

77 J. Ficowski, Sima omnivora erecta [w:] tegoż, Pismo obrazkowe, Warszawa 1962, s. 30.

${ }^{78}$ M. Mikołajczak, dz. cyt., s. 67. 
Machowska M., Bronistawa Wajs Papusza. Między biografia a legenda, Kraków 2011.

Mikołajczak M., Co zostato na dnie „kulturowego tygla”? Powroty do miejsc utraconych w twórczości najstarszego pokolenia lubuskich poetów [w:] tejże, Zbliżenia. Studia i szkice poświęcone literaturze lubuskiej, Zielona Góra 2011.

Miller N.K., Arachnologie: kobieta, tekst i krytyka, tłum. K. Kłosińska, K. Kłosiński [w:] Teorie literatury XX wieku. Antologia, red. A. Burzyńska, M.P. Markowski, Kraków 2006.

Mirga A., Mróz L., Cyganie. Odmienność i nietolerancja, Warszawa 1994.

Mróz L., Dzieje Cyganów-Romów w Rzeczpospolitej XV-XVIII w., Warszawa 2001.

O Romach $w$ Polsce i Europie. Tożsamość, historia, kultura, edukacja, red. P. Borek, Kraków 2009.

Papusza, czyli Wielka tajemnica, wyb. tekstów i posł. K. Kamińska, Gorzów Wielkopolski 1992.

Prokop-Janiec E., Etnopoetyka [w:] Kulturowa teoria literatury 2. Poetyki, problematyki, interpretacje, red. T. Walas, R. Nycz, Kraków 2012.

Przyboś J., Papusza i pieśń ludowa, „Przegląd Kulturalny” 1956, nr 20.

Romowie w Polsce i Europie - historia, prawo, kultura, red. P. Borek, Kraków 2007.

Sobczak M., „Czy bajką byto to, czy prawdą?. Próba demitologizacji Bronistawy Wajs (Papuszy) [w:] Miejsce i tożsamość. Literatura lubuska w perspektywie poetyki przestrzeni i antropologii, red. M. Mikołajczak, K. Gieba, M. Sobczak, Zielona Góra 2013.

Sobieska A., Dzieci Hagar. Literackie wizerunki Romów/Cyganów. Studia imagologiczne, Warszawa 2015.

Studia o Romach w Polsce i w Europie, red. P. Borek, Kraków 2013.

Szymborska W., Pieśni Papuszy, „Życie Literackie” 1956, nr 19.

Waldenfels B., Podstawowe motywy fenomenologii obcego, tłum. J. Sidorek, Warszawa 2009.

Waśkiewicz A.K., Papusza \& Ficowski, „Ziemia Gorzowska”, luty 1974.

Waśkiewicz A.K., Papusza. Szkic do portretów, „Nadodrze” 1963, nr 6.

White K., Geopoetyki, wyb., tłum. K. Brakoniecki, Olsztyn 2014.

White K., Poeta kosmograf, wyb., tłum. K. Brakoniecki, Olsztyn 2010. 